\title{
PREDICTING INTENDED UNETHICAL BEHAVIOUR AMONG COLLEGE OF ECONOMICS AND BUSINESS STUDENTS: AN EMPIRICAL STUDY AT UNIVERSITAS GADJAH MADA
}

\author{
Sari Winahjoe \\ Faculty of Economics and Business \\ Universitas Gadjah Mada \\ (winahjoesari@yahoo.com) \\ Sudiyanti \\ Faculty of Economics and Business \\ Universitas Gadjah Mada \\ (sudiyanti@ugm.ac.id)
}

\begin{abstract}
This study attempted to examine the intention to act in an unethical manner among the economics and business students in Universitas Gadjah Mada by applying the Theory of Planned Behaviour. Attitude, subjective norms, perceived personal outcome, perceived social acceptance, and perceived behavioural control were included in predicting this intention. A total of 208 students participated in the main investigation. Using ordinal regression, 3 hypothetical unethical situations were proposed to measure the students' intended behaviour: (1) having the class attendance list signed by a classmate; (2) cheating in an examination or quiz; and (3) knowingly plagiarising someone else's work. The results confirmed that attitude was the strongest predictor of a student's intention to act in an unethical manner. The study findings also supported subjective norms as the second strongest predictor, which was followed by perceived personal outcome and perceived social acceptance as determinants of such behavioural intention. Meanwhile, the findings demonstrated that perceived behavioural control was the weakest predictor of intention. Analysis for each situation, implications for practitioners, specifically university teachers and education policy makers, and further research recommendations are also discussed.
\end{abstract}

Keywords: theory of planned behaviour, course of ethics, education policy, behavioural intention

\section{INTRODUCTION}

Over the past several decades, the area of business ethics has received considerable attention from the corporate, academic, and public sectors (Conroy \& Emerson, 2004: 383). The recent scandals in Indonesia, -such as the cases of bribery in the Hambalang project, the driving license simulator procurement project, or Gayus Tambunan, a tax official wanted for corruption and money laundering, which came under the spotlight after the police named him as a suspect in connection with a suspicious 25 billion Rupiah bank account in his name (ANTARA,
2010) - should be eye-opening occurrences for the public and specifically for employers to consider ethical behaviour before or during the recruitment process is completed.

Business educators have recognized that there is a growing realization and need to incorporate a discussion of ethical issues into the curriculum and discussions of ethics are a desirable and perhaps essential component of business education (Randall, 2004: 369). With those recent scandals, the issues of unethical behaviour also induced economics and business colleges to embrace ethics in their teaching learning objec- 
tives, curriculum, program learning goals, and university mission statements.

Furthermore, according to Conroy \& Emerson (2004: 384), the business leaders acknowledge that they feel business students should be exposed to business ethics and for this reason, the Association to Advance Colleges and Schools of Business (AACSB) in 1974 promptly included "ethical considerations" in its body of required knowledge.

Indeed, the aspects of teaching ethics in economics and business colleges have been extensively observed by many theoretical and empirical researches, such as the importance of business ethics for students, the reasons for taking elective business ethics courses, ethical decisionmaking, trainability of ethics, the gender difference proclivity for unethical behaviour, both in academic and work environment settings, the propensity to engage in illegal business practices and predicting the intention to act in an unethical manner (Adkins \& Radtke (2004); Chang (1998); Randall (1994), Betz et al., (1989); Duizend \& McCann (1998); and Ritter (2006)). However, to the best of our knowledge, little research work has been publicly focused in explaining and predicting the intention to act unethically, specifically among the economics and business students.

In investigating behavioural intention, the most commonly used theory is the Theory of Planned Behaviour (Ajzen, 1991). According to this theory, an individual usually does what she or he intended to do, and this intention is one of the major determinants of whether she or he will perform this specific behaviour in the future.

By applying a similar model and additional predictor from Wilson (2008), this study attempted to examine the intention to act with unethical behaviour among the economics and business students.

\section{Objective of the Study}

3 hypothetical unethical situations were used to measure the students' intended behaviour, which are: (1) having the class attendance list signed by a classmate; (2) cheating in an examination or quiz; and (3) plagiarising another's work. The main purpose of this study is to examine what the likelihood is that economics and business students would intend to act unethically in the campus environment, specifically in these 3 hypothetical unethical situations. The results are hoped to provide a new insight on the importance of students taking business ethics courses and its implementation in their real-life, specifically in their learning environment, so that the findings of this study can facilitate economics and business colleges and schools to develop more effective business ethics teaching programs, curriculum, and codes of conduct.

\section{Literature Review}

Principally, the research model in this study is based on the theory of planned behaviour (Ajzen, 1991), which is the extension of the theory of reasoned action that was initially developed by Fishbein \& Ajzen (1975). According to this theory, attitude is a function of behavioural beliefs, outcome evaluations of beliefs, and the number of salient outcomes. Meanwhile, Mathieson (1991) stated that behavioural belief refers to the subjective probability that a person's behaviour will lead to a particular outcome, while an outcome evaluation expresses a rating of the desirability of the outcome.

As mentioned by Ajzen (1991), the subjective norm is a function of normative beliefs that reflect the likelihood that important referent individuals or groups suggest or do not suggest performing a given behaviour and motivation to comply across the number of salient others. Among the beliefs that ultimately determine intention and action, a set of presence or absence of requisite resources and opportunities lies. This argument brings us to a term of perceived behavioural control, which is computed as a function of the control beliefs and perceived power of the control factor to facilitate or inhibit performance of the behaviour across the salient control beliefs. Ajzen also argues that as a general rule, if one perceives that she or he has a more favourable attitude and subjective norms, and the greater perceived control over performing the 
behaviour, the person is more likely to form a strong intention to perform the behaviour.

Taken as a whole, the built-in model in the Theory of Planned Behaviour explains a general rule that if one perceives that she or he has a more favourable attitude and subjective norms, and the greater perceived control over performing the behaviour, the person is more likely to form a strong intention to perform the behaviour.

During the past decade, the Theory of Planned Behaviour has been employed to examine a wide variety of behaviour with considerable success. They include examining the intention to recycle wastepaper, attitude and pro-environmental action, intention to softlifting or illegally duplicating the copyrighted software by individuals for personal use, trying to consume, risk perception and trust in food safety information, predicting user intentions towards new computer system (e.g., Mathieson, 1991), and also examining the intention to purchase organic foods and genetically modified food products (e.g., Cheung et al., 1999; Goles et al., 2008; Lobb et al., 2007; Bagozzi \& Warshaw, 1990; Chen, 2007; Sparks et al., 1997; Bredahl et al.,1998; Cook et al., 2002; and Townsend \& Campbell, 2004).

In the area of business ethics, the Theory of Planned Behaviour has also been applied as the theoretical foundation. For instance, research has explored why students sign up for an elective ethics course (Randall, 1994). 178 graduate students in Ireland were surveyed about their intention to sign up for an elective ethics class. Their behaviour was measured 2 months later. The findings revealed that the Theory of Planned Behaviour provided a useful theoretic foundation to help understand the student's choices. A combination of attitude toward enrolling in the ethics course, the subjective norm and perceived behavioural control could explain approximately 37 percent of the variance in the intent to enrol in the class and 14 percent of the variance in attendance could be explained by intention. The power of the model in predicting intention clearly derives from the attitude toward enrolling in the class and, to a lesser extent, the perceived behavioural control. Interestingly, the subjective norm did not have a significant impact on the intent to enrol in the elective ethics course. Ultimately, it appears that a student's decision to enrol in an elective ethics course is largely a function of the attitude $s($ he) holds towards taking that course, and this intention is slightly tempered by how much control the student feels $\mathrm{s}($ he) has about taking the course. The Theory of Planned Behaviour set forth that there is little to be gained by consideration of demographic or personality variables. This study confirmed that individual difference variables were largely captured by the determinants of intent, and that demographic or personality variables have no direct effect on the intention behaviour relationship.

Another work took a different method in predicting unethical behaviour. A researcher has challenged the robustness of 2 theories: the Theory of Reasoned Action and the Theory of Planned Behaviour (Chang, 1998). This research sample involved 181 university students. Using Structural Equation Modelling, the study assessed the influence of attitude, subjective norm, and perceived behavioural control on the intention to make unauthorized software copies. Furthermore, the modified version of the Theory of Planned Behaviour, with a causal path linking the subjective norm to attitude, presented a significant improvement on the model fit. Unlike the result of the Theory of Planned Behaviour, in which attitude was found to be the most significant determinant (Ajzen, 2002), the research finding of Chang (1998) demonstrated that the perceived behavioural control is a better predictor of behavioural intention than attitude. The result also designated that the direct effect of the subjective norm on behavioural intention was not significant, but the indirect effect through attitude was highly significant. Overall, compared to the Theory of Reasoned Action, the findings indicated that the Theory of Planned Behaviour was the better in predicting unethical behaviour.

From all the explanations above, the following types of hypothesis statements are to be addressed and applicable for all hypothetical situations: 
$\mathrm{H}_{1}$ : Students' intention to have the class attendance list signed by a classmate will be significantly influenced by their attitude toward the behaviour, subjective norms, perceived behavioural control, perceived personal outcome, and perceived social acceptance by others.

$\mathrm{H}_{2}$ : Students' intention to cheat in an examination or quiz will be significantly influenced by their attitude toward the behaviour, subjective norms, perceived behavioural control, perceived personal outcome, and perceived social acceptance by others.

$\mathrm{H}_{3}$ : Students' intention to plagiarise will be significantly influenced by their attitude toward the behaviour, subjective norms, perceived behavioural control, perceived personal outcome, and perceived social acceptance by others.

\section{Present Study}

The research model in this study is presented in Figure 1, which illustrates the hypothesized relationships between the independent variables and dependent variable.

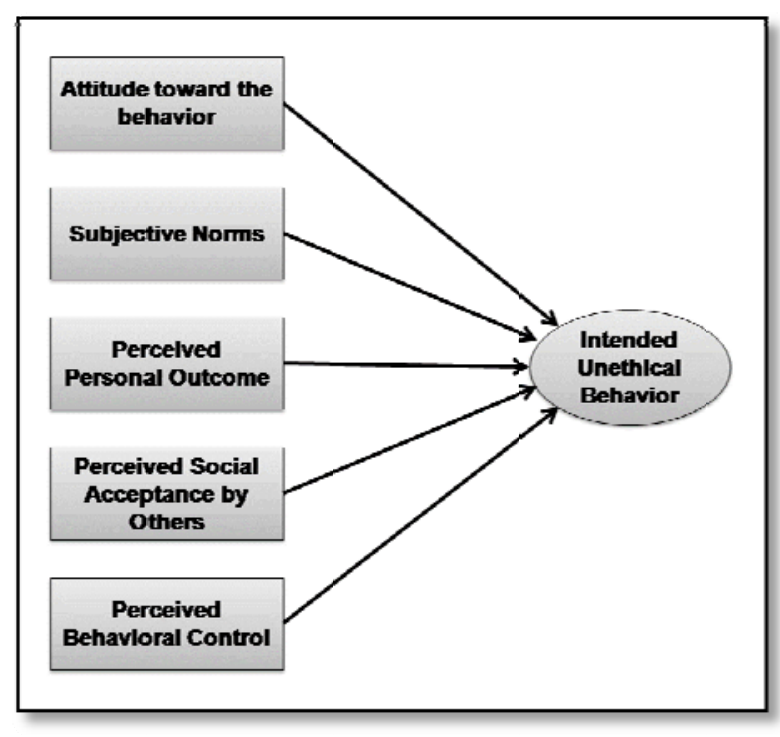

Source: Adopted from Wilson (2008)

Figure 1. Research Model

The similarity here between the research model and the Theory of Planned Behaviour is that the three main elements of the Theory of Planned Behaviour are being adopted as the determinants of behavioural intention. Unlike the original theory, the Perceived Personal Outcome and Perceived Social Acceptance by Others are also presented in the proposed model as predictors of behavioural intention.

This study refers mostly to the previous work of Wilson (2008). In his research, Wilson measured business students' intended behaviour for these following determinants: attitude, subjective norms, perceived behavioural control, perceived personal outcome, and perceived social acceptance. The results confirmed that perceived behavioural control, perceived personal outcome and perceived social acceptance by others were moderately good predictors of intention. Furthermore, attitude was indicated as being the most powerful determinant of the behavioural intention, while the subjective norm was shown to be the weakest predictor.

\section{METHOD}

\section{Sample}

We employed the convenience method in the sampling process. A total of 208 students participated in the main investigation. They came from 3 departments: business (management), accounting, and economics - in the Faculty of Economics and Business at Gadjah Mada University. All the participants were taken from the Business Communication course, 'Introduction to Business, Business Ethics, and Global Marketing', which represent both the regular and international undergraduate program and is common to all 3 departments. We obtained data from 112 (53.8 percent) female students and 96 (46.2 percent) male students. We do not claim that these convenience samples represent the national population of university students or the specific disciplines.

\section{Development of the Questions and \\ Situations}

There were two main focuses of the pilot project. First, was to develop the hypothetical situations. For this purpose, 60 students were requested to identify and list as many unethical situations as possible that might occur related to their learning process both on and off campus. 
We called this step 'Pilot Project Stage 1'. Once we received our lists of hypothetical situations, the next step was to conduct a focus group (Stage 2). We invited 11 students to participate in this focus group. The members involved at this stage were to offer clarity and share their interpretation of all the listed possible unethical situations. In the end, the focus group provided the proposed research with a vehicle to obtain a more constricted 7 hypothetical situations list, which can be used for the main investigation. However, for the sake of brevity, this article only discusses 3 of them, which were rated by the students as the top 3 intended unethical behaviours. The 3 have been stated earlier in the article.

\section{Measurements and Data Collecting Methods}

Primary data is required to provide the information value or degree for each of the key variables (attitude, subjective norms, perceived behavioural control, perceived personal outcome, perceived social acceptance, and intended unethical behaviour). There are many methods of data collection. The research study employed a survey technique as the primary data collecting method. For this purpose, self-administered questionnaires (a printed questionnaire) were utilized as the data collecting devices. Intended unethical behaviour (dependent variable) was measured by the following determinants: attitude toward the behaviour, subjective norms, perceived behavioural control (Ajzen, 2002), perceived personal outcomes, and perceived social acceptance by others (Pratt \& McLaughin, 1989; Nonis \& Swift (2001); and Wilson (2008)). In addition, some other variables such as sex and degree course were collected, but only for the respondents' profiling.

Behavioural intention is a function of 3 basic determinants, which are the attitude toward the behaviour, subjective norms regarding the behaviour, and perceived behavioural control. According to Hoyer and Maclnnis (2007), attitude is an overall evaluation that expresses how much we like or dislike an object, issue, person, or action. It is learned, tends to persist over time, and reflects an overall evaluation of something based on the set of associations linked to it. Meanwhile, Schiffman \& Kanuk (2007: 238) defines attitude as a learned pre-disposition to behave in a consistently favourable or unfavourable way with respect to a given object.

Moreover, the subjective norm is defined as the degree of social pressure felt by the person with regard to the behaviour, while the perceived behavioural control refers to the degree of control that the person feels he or she has over performing the behaviour which determines the perceived behavioural control (Ajzen, 2002). The expanded work of the Theory of Planned Behaviour, which was done by Pratt and McLaughlin (1989) indicated an underlying structure that influences perceptions on the basis of the amount of benefit received, the difficulty and the probability of getting caught when performing a behaviour (in Wilson, 2008: 188). This context leads us to the definition of perceived personal outcomes. According to Nonis \& Swift (2001), an individual is likely to engage in dishonest acts if she or he believes that dishonest acts are acceptable to other individuals. This situation is called the perceived social acceptance by others. The complete responses included are presented in the Table 1.

\section{Data Analysis}

In analyzing the data, we employed an ordinal regression analysis. Unlike other regression analyses, an ordinal regression analysis is used when we would like to examine how the influence of several independent variables influence a dependent variable that has an ordinal scale. In this study, we have investigated how likely these 5 measured independent variables: students' attitude, subjective norms, perceived behavioural control, benefit, and social acceptance by others are in determining the intention to performing behaviour that would be considered unethical. These five independent variables were called the location components.

In the ordinal regression analysis, there are 5 options of link functions. The link function is a transformation of the cumulative probabilities that allows an estimation of the model. These 5 
link functions are: logit, complementary log-log, negative $\log -\log$, probit, and cauchit. Frequency distribution of the responses for the dependent variable is used in selecting which link function is appropriate. We use probit when the latent variable is normally distributed, while negative $\log$-log is appropriate when lower categories are more probable. As Table 2 shows, the 1 st and 2nd unethical situations have a normal distribution for their latent variable; therefore, we used the probit function. We applied the negative log$\log$ for the 3rd unethical situations as there were more responses in the lower categories.

\section{RESULTS}

As shown in Table 2, 86 of the 208 students said that once in a while they would intend to have their attendance list signed by a classmate. Yet, this behaviour is perceived as difficult to do (36.5 percent) and believed to be unethical (59 percent).Other independent variable responses for having the attendance list signed by their classmate demonstrate that 38.9 percent of the students would feel quite a bit of pressure from their fellow group members; 36.5 percent presumed that other people in their community would say that this behaviour is borderline risky and 49 percent thought the benefit was definitely not worth the risk.

Table 1. Measurement of All Included Variables

\begin{tabular}{|c|c|c|}
\hline Variable & Question & Response Anchors \\
\hline \multicolumn{3}{|l|}{ Independent Variables: } \\
\hline Attitude & $\begin{array}{l}\text { "You believe that this behaviour } \\
\text { is..." }\end{array}$ & $\begin{array}{l}1 \text { (unethical), } 2 \text { (somewhat unethical), } 3 \\
\text { (borderline), } 4 \text { (somewhat ethical), } 5 \\
\text { (ethical) }\end{array}$ \\
\hline Subjective Norms & $\begin{array}{l}\text { "You would feel pressure to do } \\
\text { this..." }\end{array}$ & $\begin{array}{l}1 \text { (none), } 2 \text { (not very much), } 3 \text { (maybe } \\
\text { some), } 4 \text { (some), } 5 \text { (quite bit) }\end{array}$ \\
\hline $\begin{array}{l}\text { Perceived Behavioural } \\
\text { Control }\end{array}$ & $\begin{array}{l}\text { "You believe that carrying this } \\
\text { behaviour would be..." }\end{array}$ & $\begin{array}{l}1 \text { (very difficult), } 2 \text { (difficult), } 3 \text { (could be } \\
\text { either), } 4 \text { (easy), } 5 \text { (very easy) }\end{array}$ \\
\hline $\begin{array}{l}\text { Perceived Personal } \\
\text { Outcome }\end{array}$ & $\begin{array}{l}\text { "Weighing the benefit and the risk } \\
\text { of being caught, you decide that } \\
\text { the benefit is..." }\end{array}$ & $\begin{array}{l}1 \text { (definitely not worth the risk), } 2 \text { (not } \\
\text { worth the risk), } 3 \text { (borderline risky), } 4 \\
\text { (worth the risk), } 5 \text { (definitely worth the } \\
\text { risk) }\end{array}$ \\
\hline $\begin{array}{l}\text { Perceived Social } \\
\text { Acceptance by Others }\end{array}$ & $\begin{array}{l}\text { "Other people in your } \\
\text { environment would view this } \\
\text { behaviour as..." }\end{array}$ & $\begin{array}{l}1 \text { (unethical), } 2 \text { (somewhat unethical), } 3 \\
\text { (borderline), } 4 \text { (somewhat ethical), } 5 \\
\text { (ethical) }\end{array}$ \\
\hline \multicolumn{3}{|l|}{ Dependent Variable: } \\
\hline $\begin{array}{l}\text { Intention to Perform the } \\
\text { Behaviour }\end{array}$ & "You would do this..." & $\begin{array}{l}1 \text { (never), } 2 \text { (once in a while), } 3 \\
\text { (occasionally), } 4 \text { (Often), } 5 \text { (at every } \\
\text { opportunity) }\end{array}$ \\
\hline
\end{tabular}

Source: Wilson (2008)

Table 2. Frequency Distribution of the Dependent Variable of Intended Behaviour $(N=208)$

\begin{tabular}{|c|c|c|c|c|c|}
\hline \multirow{2}{*}{$\begin{array}{l}\text { Unethical } \\
\text { Situation }\end{array}$} & \multicolumn{5}{|c|}{ Response } \\
\hline & 1 (Never) & 2 (Once in a while) & 3 (Occasionally) & 4 (Often) & 5 (At every opportunity) \\
\hline Class attendance & 30 & 86 & 85 & 4 & 3 \\
\hline Cheating & 70 & 73 & 56 & 3 & 6 \\
\hline Plagiarism & 85 & 77 & 42 & 3 & 1 \\
\hline
\end{tabular}


In the 2nd unethical situation, cheating in an examination or quiz, 73 students said they would cheat once in a while, and 33.7 percent of them claimed that they will never cheat in the examinations or quizzes. These findings are probably reasonable since 78.4 percent of the students believed that cheating is unethical, difficult to do (40.4 percent), and the benefit is definitely not worth the risk (43.8 percent). Of the 208 students, 44.7 percent would feel quite a bit of pressure from their fellow group members and 38.9 percent presumed that other people in their community would see cheating as unethical behaviour.

The 3rd observed unethical situation is plagiarism. Of all the students, 85 said they would never have any intention to do plagiarise. The independent variable responses for this category demonstrate that 80.3 percent of students believed that plagiarism is unethical, 40.9 percent felt some pressure from their colleagues and faculty staffs, 46.2 percent believed that the benefit was definitely not worth the risk, and 50.5 percent presumed that other people believe this is unethical. The response scores for perceived behavioural control are proportionally distributed. The results show that carrying out plagiarism was perceived as easy (22.6 percent), could be either (22.1 percent), difficult ( 24 percent) and very difficult (20.7 percent) by the students.

\section{Unethical Situation 1: Having the class atten- dance list signed by a classmate}

Overall, the test of the null hypothesis stated that the location coefficients for all of the variables in the model are 0 (zero). The Model Fitting Information for this situation showed that $\chi^{2}(20, \mathrm{~N}=208)=54.553$ with an observed significance level of less than .005. This means that we can reject the null hypothesis that the model without predictors is as good as the model with the predictors. The Pseudo $\mathrm{R}^{2}$ measures $($ Cox and Snell $=.231$, Nagelkerke $=.257$, and McFadden $=.114$ ) demonstrated that the model performs fairly well. For location-only models, the test of parallel lines assesses whether the parameters are the same for all categories. Since the Log-likelihood value of the general model is smaller than that of the null model, the test of parallel lines could not be performed.

As shown in Table 3, perceived social acceptance by others is the only variable that does not have a negative coefficient, while attitude, subjective norms, perceived behavioural control and perceived personal outcome mostly have negative coefficients. These negative coefficients point out the lower values in attitude, subjective norms, perceived behavioural control, and perceived personal outcome decrease the probability of the students' intention to have the class attendance list signed by a classmate.

From all the observed significance levels, attitude has 3 significant coefficients (unethical, $\mathrm{p}=.001$, somewhat unethical, $\mathrm{p}=.008$, borderline, $\mathrm{p}=.007$ ), subjective norms has 1 significant coefficient (some, $\mathrm{p}=.046$ ) and 2 marginal coefficients (not very much, $\mathrm{p}=.057$, maybe some, $\mathrm{p}=.091)$. Perceived personal outcome has 2 significant coefficients (definitely not worth the risk, $\mathrm{p}=.010$, borderline risky, $\mathrm{p}=.043$ ) and 1 marginal coefficient (not worth the risk, $p=$ 090). Furthermore, perceived social acceptance by the other variable has 1 marginal coefficient (borderline, $\mathrm{p}=.085$ ). These results imply that attitude, subjective norms, perceived personal outcome and perceived social acceptance by others are determinants of the students' intention to have the class attendance list signed by their classmates, while perceived behavioural control is not a predictor. Therefore, we reject $\mathrm{H}_{1}$.

\section{Unethical Situation 2: Cheating in an examination or quiz}

The Model Fitting Information for the 2nd unethical situation showed that $\chi^{2}(20, \mathrm{~N}=208)$ $=147.981, \mathrm{p}<.005$, therefore, the null hypothesis (that all independent variables are equal to zero) is rejected. The Pseudo $\mathrm{R}^{2}$ measures (Cox and Snell $=.509$, Nagelkerke $=.555$, and McFadden $=.284$ ) indicated that the model performs fairly well. For the test of Parallel Lines measures, the $\chi^{2}$ statistic $(5.482, p>.001)$ is computed based on the log-likelihood value of the last iteration of the general model. The validity of the test is uncertain. 
Table 3. Having the class attendance list signed by a classmate: Ordinal Regression Parameter Estimates for the Dependent and Independent Variables

\begin{tabular}{|c|c|c|c|c|c|c|}
\hline Variable & Response & Estimate & $S E$ & Wald & $d f$ & Sig. \\
\hline \multicolumn{7}{|l|}{ Treshold } \\
\hline \multirow[t]{5}{*}{ INT } & 1 (never) & -4.241 & 1.076 & 15.530 & 1 & .000 \\
\hline & 2 (once in a while) & -2.822 & 1.076 & 6.989 & 1 & .008 \\
\hline & 3 (occasionally) & -.842 & 1.047 & .649 & 1 & .421 \\
\hline & 4 (Often) & -.468 & 1.048 & .199 & 1 & .655 \\
\hline & 5 (at every opportunity) & & & & & \\
\hline \multicolumn{7}{|l|}{ Location } \\
\hline \multirow[t]{5}{*}{ ATT } & 1 (unethical) & -2.975 & .900 & 10.923 & 1 & .001 \\
\hline & 2 (somewhat unethical) & -2.416 & .908 & 7.084 & 1 & .008 \\
\hline & 3 (borderline) & -2.448 & .902 & 7.359 & 1 & .007 \\
\hline & 4 (somewhat ethical) & -1.527 & 1.127 & 1.836 & 1 & .175 \\
\hline & 5 (ethical) & $0^{\mathrm{a}}$ & . & . & 0 & \\
\hline \multirow{5}{*}{ SUN } & 1 (none) & -.121 & .318 & .144 & 1 & .704 \\
\hline & 2 (not very much) & .495 & .260 & 3.629 & 1 & .057 \\
\hline & 3 (maybe some) & .427 & .252 & 2.865 & 1 & .091 \\
\hline & 4 (some) & .486 & .244 & 3.966 & 1 & .046 \\
\hline & 5 (quite bit) & $0^{\mathrm{a}}$ & . & . & 0 & \\
\hline \multirow[t]{5}{*}{$\mathrm{PBC}$} & 1 (very difficult) & -.172 & .495 & .120 & 1 & .729 \\
\hline & 2 (difficult) & -.061 & .467 & .017 & 1 & .896 \\
\hline & 3 (could be either) & .149 & .478 & .097 & 1 & .755 \\
\hline & 4 (easy) & .060 & .500 & .014 & 1 & .905 \\
\hline & 5 (very easy) & $0^{\mathrm{a}}$ & & & 0 & \\
\hline \multirow[t]{5}{*}{ PPO } & 1 (definitely not worth the risk) & -1.015 & .395 & 6.623 & 1 & .010 \\
\hline & 2 (not worth the risk) & -.680 & .400 & 2.882 & 1 & .090 \\
\hline & 3 (borderline risky) & -.906 & .448 & 4.103 & 1 & .043 \\
\hline & 4 (worth the risk) & -.633 & .428 & 2.185 & 1 & .139 \\
\hline & 5 (definitely worth the risk) & $0^{\mathrm{a}}$ & & 0 & 0 & \\
\hline \multirow[t]{5}{*}{ PSA } & 1 (unethical) & .396 & .313 & 1.605 & 1 & .205 \\
\hline & 2 (somewhat unethical) & .017 & .317 & .003 & 1 & .958 \\
\hline & 3 (borderline) & .507 & .295 & 2.960 & 1 & .085 \\
\hline & 4 (somewhat ethical) & .260 & .358 & .530 & 1 & .467 \\
\hline & 5 (ethical) & $0^{\mathrm{a}}$ & . & . & 0 & \\
\hline
\end{tabular}

a. This parameter is set to zero because it is redundant. Link Function: Probit.

Table 4 shows the negative coefficients for 3 independent variables: attitude, subjective norms and social acceptance by others, meaning that lower values in attitude, subjective norms and social acceptance by others decrease the probability of the students' intention to cheat in an examination.

All coefficients for attitude have strongly significant probabilities $(\mathrm{p}<.001)$, which leads this variable to be the best predictor of students' intention to cheat. The second best predictor is subjective norms, with significant coefficients ranging from .001 to .034 . The variable of perceived personal outcome is the next best determinant of cheating, which has 3 significant coefficients (not worth the risk, $p=.011$, borderline risky, $\mathrm{p}=.002$, worth the risk, $\mathrm{p}=.008$ ). Perceived social acceptance by others is the next best predictor, with 2 significant coefficients (unethical, $\mathrm{p}=.019$, borderline, $\mathrm{p}=.031$ ) and 1 marginal coefficient (somewhat ethical, $\mathrm{p}=$ .581). The least predictive factor of a students' intention to cheat in an examination or quiz is perceived behavioural control, which has 1 significant coefficient (easy, $\mathrm{p}=.013$ ) and 1 marginal coefficient (difficulty, $\mathrm{p}=.092$ ). Based on these findings, $\mathrm{H} 2$ is confirmed. 
Table 4. Cheating in an examination or quiz: Ordinal Regression Parameter Estimates for the Dependent and Independent Variables

\begin{tabular}{|c|c|c|c|c|c|c|}
\hline Variable & Response & Estimate & $S E$ & Wald & $d f$ & Sig. \\
\hline \multicolumn{7}{|l|}{ Treshold } \\
\hline \multirow[t]{5}{*}{ INT } & 1 (never) & -9.291 & 1.364 & 46.410 & 1 & .000 \\
\hline & 2 (once in a while) & -7.889 & 1.370 & 33.154 & 1 & .000 \\
\hline & 3 (occasionally) & -6.050 & 1.372 & 19.452 & 1 & .000 \\
\hline & 4 (Often) & -5.734 & 1.375 & 17.384 & 1 & .000 \\
\hline & 5 (at every opportunity) & & & & & \\
\hline \multicolumn{7}{|l|}{ Location } \\
\hline \multirow[t]{5}{*}{ ATT } & 1 (unethical) & -9.980 & .886 & 126.921 & 1 & .000 \\
\hline & 2 (somewhat unethical) & -9.921 & .907 & 119.616 & 1 & .000 \\
\hline & 3 (borderline) & -9.502 & .902 & 111.010 & 1 & .000 \\
\hline & 4 (somewhat ethical) & -8.887 & .000 & 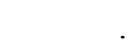 & 1 & \\
\hline & 5 (ethical) & $0^{\mathrm{a}}$ & & . & 0 & \\
\hline \multirow[t]{5}{*}{ SUN } & 1 (none) & -.864 & .408 & 4.493 & 1 & .034 \\
\hline & 2 (not very much) & 1.053 & .261 & 16.275 & 1 & .000 \\
\hline & 3 (maybe some) & .580 & .273 & 4.529 & 1 & .033 \\
\hline & 4 (some) & .726 & .240 & 9.128 & 1 & .003 \\
\hline & 5 (quite bit) & $0^{\mathrm{a}}$ & 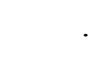 & 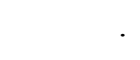 & 0 & \\
\hline \multirow[t]{5}{*}{$\mathrm{PBC}$} & 1 (very difficult) & .689 & .910 & .574 & 1 & .449 \\
\hline & 2 (difficult) & 1.522 & .904 & 2.836 & 1 & .092 \\
\hline & 3 (could be either) & 1.407 & .915 & 2.365 & 1 & .124 \\
\hline & 4 (easy) & 2.424 & .977 & 6.154 & 1 & .013 \\
\hline & 5 (very easy) & $0^{\mathrm{a}}$ & & & 0 & \\
\hline \multirow[t]{5}{*}{ PPO } & 1 (definitely not worth the risk) & .252 & .322 & .611 & 1 & .434 \\
\hline & 2 (not worth the risk) & .831 & .328 & 6.440 & 1 & .011 \\
\hline & 3 (borderline risky) & 1.226 & .399 & 9.470 & 1 & .002 \\
\hline & 4 (worth the risk) & 1.075 & .406 & 7.006 & 1 & .008 \\
\hline & 5 (definitely worth the risk) & $0^{\mathrm{a}}$ & & & 0 & \\
\hline \multirow[t]{5}{*}{ PSA } & 1 (unethical) & -.983 & .419 & 5.502 & 1 & .019 \\
\hline & 2 (somewhat unethical) & -.705 & .435 & 2.622 & 1 & .105 \\
\hline & 3 (borderline) & -.938 & .435 & 4.636 & 1 & .031 \\
\hline & 4 (somewhat ethical) & -.294 & .533 & .304 & 1 & .581 \\
\hline & 5 (ethical) & $0^{\mathrm{a}}$ & & & 0 & \\
\hline
\end{tabular}

a. This parameter is set to zero because it is redundant. Link Function: Probit.

\section{Unethical Situation 3: Plagiarism}

Good models have a large observed significance level. The goodness-of-fit measures for the 3rd unethical situation have large observed significance levels (Pearson $=358.484, \mathrm{p}=$ 1.000 and Deviance $=239.492, \mathrm{p}=1.000$ ), so it appears that the model fits. The model fitting information demonstrated that the fitness of the model for the 3rd unethical situation is $\chi^{2}=$ $138.948, \mathrm{p}<.001$, so the null hypothesis (that the location coefficients for all of the variables in the model are 0 ) can be rejected. The pseudo $\mathrm{R}^{2}$ measures $(\mathrm{Cox}$ and Snell $=.487$, Nagelkerke $=.542$, and McFadden $=.292)$ indicated that the model performed moderately well. The test of parallel lines shows that $\chi^{2}(60, \mathrm{~N}=208)=$ $279.900, \mathrm{p}<.001$, entailed that regression coefficients are reasonably different for each category. 
Table 5. Plagiarism: Ordinal Regression Parameter Estimates for Dependent and Independent Variables

\begin{tabular}{|c|c|c|c|c|c|c|}
\hline Variable & Response & Estimate & $S E$ & Wald & $d f$ & Sig. \\
\hline \multicolumn{7}{|l|}{ Treshold } \\
\hline INT & $\begin{array}{l}1 \text { (never) } \\
2 \text { (once in a while) } \\
3 \text { (occasionally) } \\
4 \text { (often) } \\
5 \text { (at every opportunity) }\end{array}$ & $\begin{array}{r}-27.664 \\
-25.832 \\
-22.824 \\
-3.034\end{array}$ & $\begin{array}{r}1.269 \\
1.277 \\
1.396 \\
1549.415\end{array}$ & $\begin{array}{r}475.449 \\
408.938 \\
267.149 \\
.000\end{array}$ & $\begin{array}{l}1 \\
1 \\
1 \\
1\end{array}$ & $\begin{array}{l}.000 \\
.000 \\
.000 \\
.998\end{array}$ \\
\hline \multicolumn{7}{|l|}{ Location } \\
\hline ATT & $\begin{array}{l}1 \text { (unethical) } \\
2 \text { (somewhat unethical) } \\
3 \text { (borderline) } \\
4 \text { (somewhat ethical) } \\
5 \text { (ethical) }\end{array}$ & $\begin{array}{r}-26.457 \\
-26.856 \\
-26.471 \\
-27.755 \\
0^{\text {a }}\end{array}$ & $\begin{array}{r}.962 \\
.965 \\
1.138 \\
.000\end{array}$ & $\begin{array}{l}755.698 \\
774.640 \\
540.632\end{array}$ & $\begin{array}{l}1 \\
1 \\
1 \\
1 \\
0\end{array}$ & $\begin{array}{r}.000 \\
.000 \\
.000 \\
.\end{array}$ \\
\hline SUN & $\begin{array}{l}1 \text { (none) } \\
2 \text { (not very much) } \\
3 \text { (maybe some) } \\
4 \text { (some) } \\
5 \text { (quite bit) }\end{array}$ & $\begin{array}{r}-.665 \\
1.240 \\
.858 \\
.481 \\
0^{\mathrm{a}}\end{array}$ & $\begin{array}{l}.569 \\
.333 \\
.314 \\
.299\end{array}$ & $\begin{array}{r}1.367 \\
13.836 \\
7.466 \\
2.581\end{array}$ & $\begin{array}{l}1 \\
1 \\
1 \\
1 \\
0\end{array}$ & $\begin{array}{r}.242 \\
.000 \\
.006 \\
.108 \\
.\end{array}$ \\
\hline PBC & $\begin{array}{l}1 \text { (very difficult) } \\
2 \text { (difficult) } \\
3 \text { (could be either) } \\
4 \text { (easy) } \\
5 \text { (very easy) }\end{array}$ & $\begin{array}{r}-1.645 \\
-.074 \\
-.012 \\
.431 \\
0^{\mathrm{a}}\end{array}$ & $\begin{array}{l}.568 \\
.371 \\
.376 \\
.388\end{array}$ & $\begin{array}{r}8.389 \\
.039 \\
.001 \\
1.236\end{array}$ & $\begin{array}{l}1 \\
1 \\
1 \\
1 \\
0\end{array}$ & $\begin{array}{l}.004 \\
.843 \\
.975 \\
.266\end{array}$ \\
\hline PPO & $\begin{array}{l}1 \text { (definitely not worth the risk) } \\
2 \text { (not worth the risk) } \\
3 \text { (borderline risky) } \\
4 \text { (worth the risk) } \\
5 \text { (definitely worth the risk) }\end{array}$ & $\begin{array}{r}-.060 \\
.489 \\
.297 \\
-.056 \\
0^{\mathrm{a}}\end{array}$ & $\begin{array}{l}.475 \\
.488 \\
.515 \\
.524\end{array}$ & $\begin{array}{r}.016 \\
1.003 \\
.333 \\
.012\end{array}$ & $\begin{array}{l}1 \\
1 \\
1 \\
1 \\
0\end{array}$ & $\begin{array}{l}.899 \\
.316 \\
.564 \\
.914\end{array}$ \\
\hline PSA & $\begin{array}{l}1 \text { (unethical) } \\
2 \text { (somewhat unethical) } \\
3 \text { (borderline) } \\
4 \text { (somewhat ethical) } \\
5 \text { (ethical) }\end{array}$ & $\begin{array}{r}-2.033 \\
-1.198 \\
-.637 \\
-.784 \\
0^{\mathrm{a}}\end{array}$ & $\begin{array}{l}.721 \\
.696 \\
.695 \\
.785\end{array}$ & $\begin{array}{r}7.953 \\
2.961 \\
.840 \\
.998\end{array}$ & $\begin{array}{l}1 \\
1 \\
1 \\
1 \\
0\end{array}$ & $\begin{array}{r}.005 \\
.085 \\
.359 \\
.318 \\
.\end{array}$ \\
\hline
\end{tabular}

a. This parameter is set to zero because it is redundant. Link Function: Negative log-log.

Table 5 illustrates the parameter estimates for independent and dependent variables. All independent variables have negative coefficients, which implies that lower values in attitude, subjective norms, perceived behavioural control, perceived personal outcome and social acceptance by others decrease the probability of a students' intention to plagiarise.

As indicated in Table 5, except for perceived personal outcome, the other independent variables: attitude, subjective norms, perceived behavioural control, and perceived social acceptance by others are determinants of the students' intention to plagiarise. All 4 coefficients for attitude have significant probabilities $(p<.005)$ that implied attitude as the best factor in influencing students' intention to plagiarise. The 2 nd best factor is the subjective norm, which has 2 significant coefficients (not very much, $\mathrm{p}<.001$, maybe some, $p=.006$ ). The next best determinant is perceived social acceptance by others, with 1 significant coefficient (unethical, $\mathrm{p}=.005$ ) and 1 marginal coefficient (somewhat unethical, $\mathrm{p}=.085$ ). The least predictive factor is perceived behavioural control, which has only 1 significant coefficient (very difficult, $p=.004$ ). Perceived personal outcome is not a predictor. From these results, we cannot confirm $\mathrm{H}_{3}$. 


\section{CONCLUSIONS AND IMPLICATIONS}

Table 6 illustrates a number of significant predictors for each unethical situation. The present study demonstrates that among the immediate predictors of a students' intention to perform unethical behaviour, attitude is the most significant and found to be the primarily predictor. This result agrees with the works of Fishbein \& Ajzen (1975), which demonstrated that among other variables, attitude toward the behaviour was found to considerably influence respondents' decisions. Another study result has confirmed that if students consider it to be unethical, then they are less likely to engage in that unethical behaviour (Chen \& Tang, 2006).

Furthermore, the study has indicated that the influence of significant others or subjective norms and perceived social acceptance by others have been moderately good determinants of students' intended unethical behaviour. Al-Rafee \& Cronan (2006), who have worked on the research topic of Digital Piracy: Factors that Influence Attitude toward Behaviour, also suggested that significant others generally supported the decision to behave unethically. Specifically, this would imply that the opinion of others does matter and it is supportive when it comes to unethical behaviour.

Moreover, the present study demonstrated that perceived personal outcome or the benefit received was the predictive factor in a students' intention toward unethical behaviour. This result is consistent with Butterfield et al. (2000) which found that individuals are more likely to recognize the moral nature of the issue when it has negative consequences and when the individuals perceive a social consensus. Another work also confirmed that the overall ethicality of a person can be predicted by social consensus, the magni- tude of consequences and the likelihood of action (Weber, 2006). Thus, the research finding supported those individuals who, in a high benefit condition, were more likely to perform unethically.

This study also provided evidence that perceived behavioural control or the likelihood of getting caught was found to be the next predictive determinant of students' intention to behave unethically. This finding provided evidence to prop up the work of previous studies, which have indicated that given the Theory of Planned Behaviour performed well, perceived behavioural control serves as an antecedent to both intention and behaviour (Mathieson, 1991; Cheung et al., 1999; Bagozzi \& Warshaw, 1990; Chen, 2007; Sparks et al., 1992; Bredahl et al., 1998; Cook et al., 2002; and Townsend \& Campbell, 2004).

Another previous work, which conducted a review of, and correlated, 107 studies of the prevalence of cheating among college students (Whitley Jr., 1998), has considerable support for the present study findings. The study has found that among the strongest correlates of cheating were having moderate expectations of success, having cheated in the past, studying under poor conditions, holding a positive attitudes toward cheating, perceiving that social norms support cheating, and anticipating a large reward for success. This implied that attitude, subjective norms, perceived behavioural control, perceived personal outcome, and perceived social acceptance by others have considerably support to be the predictors of students' intention to behave unethically.

Overall findings implied that even though ethical codes exist within the economics and business schools, they still need to be communi-

Table 6. Number of Significant Predictor (Coefficients) for Each Unethical Situation

\begin{tabular}{lccccc}
\hline \multirow{2}{*}{ Unethical Situation } & \multicolumn{5}{c}{ Predictors } \\
\cline { 2 - 6 } & ATT & SUN & PBC & PPO & PSA \\
\hline Class attendance & 3 & $1+2$ marginal & - & $2+1$ marginal & 1 marginal \\
Cheating & 3 & 4 & $1+1$ marginal & 3 & $2+1$ marginal \\
Plagiarism & 3 & 2 & 1 & - & $1+1$ marginal \\
\hline \multicolumn{1}{c}{ Total } & 9 & $7+2$ marginal & $2+1$ marginal & $5+1$ marginal & $3+3$ marginal \\
\hline
\end{tabular}


cated more forcefully. The significance level of subjective norms (SUN), perceived outcome (PPO), and perceived behavioural control (PBC) indicates the importance of external control in discouraging students to act unethically. Strict policies related to examinations and their monitoring, such as staff briefings prior to the examination need to be undertaken. The focus group discussion in the pilot project stage provided us with a clear indication that students would have the courage to, for example, wear sandals in the campus area or litter when staff (specifically, the security staff) are around, implies that we need to give full authority to the staff to warn the students, or to take staff empowerment as an important matter.

Ultimately, instead of just memorizing, ethics-related courses need to get students personally involved to deeply implant the ideas to influence their attitude (ATT) and moral development, which at the same time will influence their perceived social acceptance (PSA) toward unethical behaviour.

\section{RECOMMENDATION FOR FUTURE RESEARCH}

This study also comes with several limitations, which may be issues to be investigated in future research. 1st, this investigation only covered students and their situation in the Faculty of Economics and Business, Gadjah Mada University, which may be too specific. 2nd, this study only focused on intention, instead of behaviour. Hence, a more comprehensive approach is needed, for instance to compare the intention to act unethically between students who have passed a business ethics course and those who have not yet taken the course. The distinctions made between gender, class, program and religion seems a promising approach for future studies. Also, further studies can focus on incorporating students' intention to act unethically with their actual behaviour.

\section{REFERENCES}

AACSB, 2003. "Standards for Business Program Accreditation". Available at: http://aacsb. edu/accreditation/brc/proposedstandards03- 10-03percent20.pdf, accessed September 10, 2010.

Adkins, N., \& Radtke, R. R., 2004. "Students' and Faculty Members' Perceptions of the Importance of Business Ethics and Accounting Ethics Education: Is There an Expectations Gap?". Journal of Business Ethics, 51 (3), 279-300.

Ajzen, I., 1991. "The theory of planned behaviour". Organizational Behaviour and Human Decision Processes, 50, 179-211.

Ajzen, I., 2002. "Perceived Behavioural Control, Self-Efficacy, Locus of Control, and the Theory of Planned Behaviour". Journal of Applied Social Psychology, 32, 665-683.

Al-rafee, S., \& Cronan, T. P., 2006. "Digital Piracy: Factors that Influence Attitude toward Behaviour", Journal of Business Ethics, 63, 237-259.

ANTARA. 2010. "Gayus Tambunan Arrested". Available at: http://www.antaranews.com/ en/news/1270007628/gayus-

tambunanarrested, accessed on September 1, 2010.

Bagozzi, R. P. \& Warshaw, P. R., 1990. "Trying to Consumer", Journal of Consumer Research, 17, 127-140.

Betz, M., O’Connell, L., \& Shepard, J. M., 1989. "Gender Differences in Proclivity for Unethical Behaviour". Journal of Business Ethics, 8 (5), 321-324.

Bredahl, L., Grunert, G. \& Frewer, L. J., 1998. "Consumer attitudes and decision making with regard to genetically engineered food products: A review of the literature and a presentation of models for future research", Journal of Consumer Policy, 21, 251-277.

Butterfield, K.D., Trevino, L. K., \& Weaver, G. R., 2000. "Moral Awareness in Business Organizations: Influences of Issue-Related and Social Context Factors", Human Relations, 53, 981-1018.

Chang, M. K., 1998. "Predicting Unethical Behaviour: A Comparison of the Theory of Reasoned Action and the Theory of Planned Behaviour". Journal of Business Ethics, 17 (16), 1825-1834.

Chen, M.-F., 2007. "Consumer attitudes and purchase intentions in relation to organic foods in Taiwan: Moderating effects of 
food-related personality traits", Food Quality and Preference, 18, 1008-1021.

Chen, Y-J., \& Li-Ping Tang, T., 2006. "Attitude toward and Propensity to Engage in Unethical Behaviour: Measurement Invariance across Major among University Students", Journal of Business Ethics, 69 (1), 77-93.

Cheung, S. F., Chan, D. K. S. \& Wong, Z. S. Y., 1999. "Re-examining the Theory of Planned Behaviour in UnderstandingWastepaper Recycling", Environment and Behaviour, 31, 587-612.

Conroy, S. J., \& Emerson, T. L. N., 2004. "Business Ethics and Religion: Religiosity as a Predictor of Ethical Awareness among Students", Journal of Business Ethics, 50, 383-396.

Duizend, J., \& McCann, G. K., 1998. "Do Collegiate Business Students Show a Propensity to Engage in Illegal Business Practices?". Journal of Business Ethics, 17 (3), 229-238.

Cook, A. J., Kerr, G. N. \& Moore, K., 2002. "Attitudes and Intentions towards Purchasing Genetically Modified Food", Journal of Economic Psychology, 23, 557-572.

Fishbein, M. \& Ajzen, I., 1975. Belief, attitude, intention and behaviour: An introduction to theory and research, Addison-Wesley, MA.

Goles, T., Jayatilaka, B., George, B., Parsons, L., Chambers, V., Taylor, D. \& Brune, R., 2008. "Softlifting: Exploring determinants of attitude", Journal of Business Ethics, 77, 481-499.

Hoyer,W. D. \& Maclnnis, D. J., 2007. Consumer Behaviour, 4th edn., Houghton Mifflin.

Kejaksaan RI, 2014. "Daftar Berita Kejaksaan Republik Indonesia". Available at: http:// www.kejaksaan.go.id/berita.php, accessed on May 14, 2014.

Lobb, A. E., Mazzocchi, M. \& Traill,W. B., 2007. "Modeling Risk Perception and Trust in Food Safety Information within the Theory of Planned Behavior", Food Quality and Preference, 18, 384-395.
Mathieson, K., 1991. "Predicting user intensions: Comparing the technology". Information Systems Research, 2, 173-191.

Nonis, S., \& Swift, C.O., 2001. "An Examination of the relationship between academic dishonesty and workplace dishonesty: Amulti campus investigation". Journal of Education for Business, 77, 69 -77.

Pratt, C.B., \& McLaughlin, G.W., 1989. "Perceptual ranks of college students' ethical beliefs and behaviours". Perceptual and Motor Skills, 69, 1027 -1036.

Randall, D. M., 1994. "Why Students Take Elective Business Ethics Courses: Applying the Theory of Planned Behaviour". Journal of Business Ethics, 13 (5), 369-378.

Ritter, B. A., 2006. "Can Business Ethics be trained? A Study of Ethical Decision-making Process in Business Students". Journal of Business Ethics, 68 (2), 153-164.

Schiffman, L. G. \& Kanuk, L. L., 2007. Consumer Behaviour, 9th edn., Pearson Prentice Hall, Upper Saddle River, New Jersey, 561 pages

Sparks, P., Guthrie, C. A. \& Shepherd, R., 1997. "The Dimension Structure of the 'Perceived Behavioural Control' construct", Journal of Applied Social Psychology, 27, 418-440.

Townsend, E. \& Campbell, S., 2004. "Psychological Determinants of Willingness to Taste and Purchase Genetically Modified Food", Risk Analysis, 24, 1385-1393.

Weber, J., 2006. "Implementing an Organizational Ethics Program in an Academic Environment: the Challenges and Opportunities for the Duquesne University Schools of Business". Journal of Business Ethics, 65 (1), 23-42.

Whitley, B. E. Jr., 1998. "Factors Associated with Cheating among College Students: A Review", Research in Higher Education, 39 (3), 235-274.

Wilson, B. A., 2008. "Predicting Intended Unethical Behaviour of Business Students". Journal of Education for Business, March/April, 187-195. 